\title{
Jervell and Lange Nielsen Syndrome
}

National Cancer Institute

\section{Source}

National Cancer Institute. Jervell and Lange Nielsen Syndrome. NCI Thesaurus. Code C84793.

An autosomal recessive inherited syndrome caused by mutations in the KCNE1 and KCNQ1 genes. It is characterized by congenital hearing loss and arrhythmia. It is a form of long QT syndrome. 